\title{
Design of Subject and Developing Environment of Preschool Education
}

\section{Liliya N. Latipova}

\author{
Zagir A. Latipov
}

Kazan (Volga region) Federal University, 420008, Kazan, Russia

Email: latipova-liliya@mail.ru

\section{Doi:10.5901/mjss.2015.v6n2s3p250}

\section{Abstract}

Relevance of the problem being researched in this article is due to the need of introduction new pedagogical technologies into the system of preschool education. The article is aimed at summarizing the first experience of design subject development environment of pre-school education laboratory established on the basis of Yelabuga Institute of Kazan Federal University. Special emphasis in the Laboratory is given to developmental subjects designed, manufactured and tested by the members of the Laboratory to determine their effectiveness in the game oriented at cognitive-developmental activities of children aged from 3 to 6-7 in kindergarten and beyond, allowing to form a fully versatile developed person. The article can be useful for educators, instructors of preschool educational institutions and rehabilitation centers in the work with children of preschool age.

Keywords: design and subject laboratory of environment preschool education development, preschool age, educational environment, educational toys, kindergarten, game.

\section{Introduction}

Nowadays Russia is experiencing new reforms in the education system at all its levels. An important and integral factor in this context is the increase of quality and efficiency especially in pre-school education, which is the first stage of education on the whole.

Theoretical basis of subject development environment of preschool education research problem in Russia is primarily determined by regulatory and local documents adopted and implemented both at regional and federal levels.

One of the main documents regulating activities of educational organizations in Russia,the Federal Law of the Russian Federation «On education in the Russian Federation» (2013), was implemented on the 1-st of September 2013.

As a result of its analysis, we have identified that educational institutions, including pre-school, should carry out educational activities with regard to the requirements of federal state educational standard, as well as exemplary educational programs of preschool education; should identify and retain a variety of educational publications, the use of pedagogically sound ways, means, methods of training and education; right on creativity, development and application of original programs and methods of training and education used in implementation of educational programs for preschool education and in accordance with article 13 when implementing educational programs can be used in a variety of educational technologies.

Today science pedagogy has an incredible amount of educational technologies, which are much wider than method itself. M. Kohler, and P. Mishra (2009) define them as complex interaction between three areas of knowledge: content, pedagogy and technology. The effectiveness of learning, in their opinion, depends on knowledge of technology. While the very basic concept of «technology» is interpreted as «newer», which allows understanding of more complex things by using simple methods (Kalimullin , 2014; Kalimullin \& Gabdilkhakov, 2014; Telegina et al., 2015).

Some of technologies are summarized, grow out of theory, while the others are practical result of research, and as for still others they have originated at the intersection of theory and practice. In any case in pre-school educational institution applied learning technologies should be aimed at reducing the «energy» on the part of an educator, the development of motivation and commitment to self-development, self-knowledge with the psycho physiological conditions of children's development. Brian D. Cox (2009) states: «Teaching methods, typically based on fixed assumptions about mind of a child to learn».

Educational psychology (Stolyarenko, 2004) defines eight periods of personality's formation depending on views of leading activity. Pre-school age, considered by us, appropriates for early childhood (3-6-7 years old). According to E. I. Ilyin (2002) 3-5 years-old children get pleasure from the game, while in half of the cases 5-years-old children prefer 
games of those who are interested to play, and at the age of 5-6 children not only gain pleasure from the process, but from results of the games.

In this regard, as noted by V.P. Valkova, children at the age of $6-7$ approach more differentially to the choice of partners in their games, calling several reasons: their ability to play in a group, ability to play well, their creative abilities in the game, assisting in the process of the game (Rybalko, 1990).

A game is the basis of teaching young children. During the game a child using a toy can get a lot of valuable learning opportunities for learning. Angie Rupan, a coordinator of «The child development Center in South San Francisco», (Трейси Geiser, 2013) says: «While playing, children begin to understand and process the world». Having worked more than 20 years as an educator of early childhood, she confirms the following: «Children's game opens their creative potential and imagination, develops reading, thinking and problem solving skills, as well as motor skills. It forms the basis for learning».

From this we can conclude that leading activity for children of preschool age is a game aimed at cognition of surrounding world, formation of attitudes and development of relationships between peers and adults (teachers, educators, parents, family members, and so on). When designing educational environment and selecting technologies of work with children of preschool age, we will focus on teaching AIDS which would contribute to the development of children and their social adaptation in modern conditions in the process of playing a game.

\section{Methodological Framework}

In order to create conditions for implementation of innovative educational projects and programs of preschool education in accordance with the Federal Law of the Russian Federation «On education in the Russian Federation» and in accordance with the Charter of the Federal state Autonomous educational institution of higher professional education «Kazan (Volga region) Federal University» design and subject laboratory of environment preschool education development was established in Yelabuga Institute of Kazan Federal University.

It is said in the most modern encyclopedia the following (Rapacewich, 2005): «Design and subject laboratory of environment preschool education development was established by the charter of the federal state autonomous educational institution of higher professional education «Kazan (Volga region) Federal University» in Yelabuga institute of Kazan federal university».

The main tasks of design and subject laboratory of environment preschool education development of Yelabuga institute are the following:

* conducting applied (including interdisciplinary) researches in the field of education;

* engaging teachers, students and graduate students of EI KFU in scientific research of the laboratory, use of research laboratory results in the educational process of El KFU;

* training new programs of academic disciplines and teaching materials in the areas of training within the Faculty of Psychology and the Faculty of Engineering and Technology.

Having defined the methodology and goal setting of the Laboratory, we have compiled a work plan consisted of products subject domain-developing environment of preschool education, development of their design and manufacture for the first phase. At subsequent stages of the Laboratory development according to the plan we have to determine effectiveness of our development implementation in pre-school educational institution. In case of positive results of pedagogical experiment and recommendations of teachers, educators, parents, students and specialists it will be possible to direct our educational items for children of preschool age in mass production.

As any game is leading activity among preschoolers, there is a need in the objects defining educational and developmental and role play activities of children.

According to our observations, unusual items that are not often found at home attract children's attention.

In her own blog Kathryn Warner from Texas (2014) offers ideas on the organization of the educational environment of the child, she gives much attention to educational subjects, even to the way these toys and books are dispersed.

Today market offers a wide range of textile and educational products for children of preschool age, but not all parents and even educational institutions can buy them. Yelabuga Institute of Kazan Federal University with a solid base of training teachers has decided to test its capabilities in the creation and implementation of educational products. It is a new area for work and self-realization and some kind of development and experience for students. To determine up products we together with the students of engineering and technology faculty of EI KFU have studied objects of preschoolers' subjective activity. Basically the Internet offers development works of Montessori's school (2013), which has vast experience in various thematic research works of development and adaptation of a child in different social contexts. Alternative sites of finished products for child's education offer a wide range of products and different 
methodological assistance to them (2003), the online shopping with entertaining and stimulating production (2011), which is aimed to develop interest in a particular area, such as music, photography, math, arts and crafts or language.

Having studied market and consumer of kindergarten students, we have set the subject of products. In the process of determining structural and functional components of educational products, we have taken into account the psychological and pedagogical requirements for games and toys in modern conditions (Sterkina, 1995): multifunctionality, possibility of using toys in joint activities, didactic properties of toys and toys ' accessory for Handicrafts. And educational toys should have instructions or guidelines, containing age targeting, methods or applications.

According to pedagogical significance of toys, they can be classified as follows (NARC, 2005):

* Toys for practice. In this category there are toys that can be arranged in different ways or require repetition of words or sayings;

* compound toys (from several parts). They include construction games, puppets and fretwork;

* Regulation toys. Such as board games, dominoes, chess, etc.

According to educators of municipal budget preschool educational institution «Kindergarten №3 «Teremok» of Yelabuga municipal district», kids prefer to play with such textile toys as home-transformers, lace, dolls, including theatrical costumes for role-playing games and others. Taking into consideration all requirements to modern educational toys, in our Laboratory we have performed a number of product models: finger toys, tactile gloves, lace, labyrinth, sorters, etc. Students of engineering and technology faculty, studying in areas of training 051000 Vocational training (by industry) program: Decorative and applied art and design; 050100 Pedagogical education, profile training: Technology; 030600 (050502) Technology and entrepreneurship specialization: Culture of house and decorative-applied arts. First we have elaborated and approved sketches, only after this work we have developed technological design documents specifying dimensions in natural size, defined compositional decision, justified the choice of material, manufacturing technology and design, and at last we have produced economic and environmental assessment of products. The work began with the creation of a product in a single instance, while doing it we consulted with educators and made relevant amendments.

\section{Results}

With the aim of obtaining an objective assessment of our product we exhibited it at the International training seminar named «Speech development of preschool and younger school age children: Russian, national and foreign languages», held in Izhevsk, on the 27 - 30-th October, 2014. Due to subjective evaluation of its participants, the most popular among all of them became a developing textile book, meeting all psychological and pedagogical requirements.

First, this educational book is polyfunctional. It can be used for tactile abilities and qualities development, as well as for motor skills formation, including small. Different tasks for identification objects, their mapping, functionality, which contribute to the development of creativity, imagination, motivation and other important qualities of effective preschool children performance, are presented in the structural content of the book.

Secondly, our authoring can be used in the joint activities of an educator (a parent) and a student. For example, such games as «Bunny-carrot» and «What does grow on the tree? » can involve a group of children (including an adult participant as a playing partner) and to initiate joint actions (collective buildings, cooperative games and others). Almost all pages of this educational book can be used by an educator as a visual aid in the classroom, because all pages can be easily removed with the basics and have loops which are used to hold this book or to attach it to the hook.

Thirdly, this textile book implements its didactic function fully, since it includes methods of teaching a child the process of lacing, skills with a variety of clasps and fittings, observing color, shape (geometric and spherical), development of speech and rhetoric.

Fourthly, this book is entirely a product of the author's execution, which can be attributed to the decorative and applied art, in which artistic composition and color are sustained; moreover this book consists of different handmade items, forming aesthetic taste and culture of a preschool aged child.

This developing book consists of 7 sheets; it is completely made of textiles and recommended for children at the age of 3 and elder. Practically at every page of this book (all in all they are 14) there are different subject compositions in color, made of different textures of fabric, equipped with stickers, buttons, lock-outs and drawstrings.

In the framework of joint regional workshop for educators of preschool educational institutions named «Interaction. Cooperation. Support» which took place on the base of municipal budget preschool educational institution «Kindergarten №3 «Teremok» of Yelabuga municipal district» on the 27-th of February 2015 we gave its participants chance to take part in the creative process.

The laboratory staff conducted a master class for participants of the seminar, where they tried to perform developmental finger toys «Teddy Bear» and «An owl». 
They tried to create new images of these toys having found a basic shaping «keyhole». They liked the idea very much. Moreover in turn they suggested different ways of toys usage, which would contribute to the development of a preschool child personality at any age.

\section{Discussions}

During our studies of the products subject of development and environment of preschool education implementation in the framework of the Laboratory, we have determined its practical significance: the author's textile book for $3-6-7$ years old children can be the basis for improving personal development of a preschool child.

Research on the subject of development and environment of pre-school education is not completed at this stage yet. Further elaborate of written instructions and guidelines of textile-educational books usage in the educational process of preschool education is being organized recently.

\section{Conclusion}

Students of Yelabuga Institute of Kazan Federal University, including members of design and subject laboratory of environment preschool education development during the execution of educational products for children of 3-6-7 had the opportunity not only to apply all types and techniques unit-to-unit processing, manufacturing and processing textiles, wood and ornamental materials they have studied, as well as to interpret. In the process of manufacturing the textile educational book students used machine and manual seams, they demonstrated a high level of artistic and design skills. Thus, a product of design and subject laboratory of environment preschool education development of Yelabuga Institute of Kazan Federal University has been applied: members of the Laboratory suggest a very useful product while students acquire skills and sharpen professionalism.

\section{References}

Able Data. (2003). Your source for assistive technology information. From http://www.abledata.com/abledata.cfm?pageid=19327\&top= $15170 \& k s e c t i o n i d=0 \&$ discontinued $=0 \&$ viewall $=1$

Brian D. Cox (2009, December 23). Informative Development. From http://www.education.com/

Federal law of the Russian Federation «On education in the Russian Federation». (2013). From http://www.rg.ru/2012/12/30/ obrazovanie-dok.html

Ilyin, E.P. (2002). Motivation and motives. SPb.: Piter, 512 p.

Kalimullin A.M. (2014). Improvement of teachers' qualification at Kazan federal university. World Applied Sciences Journal, Vol. 30 (4), 447.

Kalimullin A.M. \& V.F. Gabdilkhakov (2014). Tutoring of pedagogical activity and new ideology of teacher training in the higher education institution. Life Science Journal, Vol. 11 (SPEC. ISSUE 11), 183.

Kathryn Warner. (2014, August 19). Kindergarten. From http://www.kindergartenkindergarten.com/

Koehler, M. J., \& Mishra, P. (2009). What is technological pedagogical content knowledge? Contemporary Issues in Technology and Teacher Education, 9(1). Retrieved from http://www.citejournal.org/vol14/iss4/

Living Montessori now. (2013). Information and Inspiration for Parents and Teachers. From http://livingmontessorinow.com/

NARC. (2005, April 11). Child care - Pedagogical Importance of Toys. From http://www.nou-nascuti.ro/child-care/pedagogicalimportance-of-toys.html.

Rapacewich, E.S. (2005). Pedagogy: Most modern encyclopedia. Minsk: Modern word, 720 p.

Rybalko, E.F. (1990). Age and differential psychology: study guide. L.: Printing house of Leningrad University, 256 p.

Sterkina, R.B. (1995). About psycho-pedagogical requirements for the games and toys in the modern environment. From http://docs.cntd.ru/document/901852366

Stolyarenko, L.D. (2004). Educational psychology. Rostov on Don: Phoenix.

The uncommon drugstore. (2011). From http://www.drugstore.com/

Telegina N.V., Galimova E.G \& Masalimova A.R. (2015).The Structure and Content of the Model of Pedagogical Conditions Binary Approach to Optimization of Control and Diagnostic Functions in Teaching "General pedagogy" to Students. Asian Social Science, Vol. 11, No. 1, 364-368, doi:10.5539/ass.v11n1p364.

Treisy G. (2013, August 27) Play in Preschool: Why it Matters. http://www.education.com/magazine/article/play-preschool-matters/ 